\title{
Events occurring during the previous lactation, the dry period, and peripartum as risk factors for early lactation mastitis in cows receiving 2 different intramammary dry cow therapies
}

\author{
P. J. Pinedo, ${ }^{\star 1}$ C. Fleming, $†$ and C. A. Risco \\ *Texas AgriLife Research-College of Veterinary Medicine \& Biomedical Sciences, Texas A\&M University, Amarillo 79106 \\ †Department of Large Animal Clinical Sciences, College of Veterinary Medicine, University of Florida, Gainesville 32608
}

\begin{abstract}
The objective of this study was to investigate the association between mastitis events occurring during the previous lactation, the dry period, and the peripartum period on the incidence of early lactation mastitis in cows receiving ceftiofur hydrochloride or penicillin dihydrostreptomycin as intramammary dry cow antibiotic therapy. Cows $(\mathrm{n}=402)$ from 2 large dairy farms in Central Florida were enrolled in the study at the time of dry-off processing and were randomly assigned to 1 of 2 dry cow therapies: ceftiofur hydrochloride or penicillin dihydrostreptomycin. Composite milk samples were collected at dry-off and after calving for bacteriological examination and somatic cell count. Peripartal health disorders were monitored during the first $30 \mathrm{~d}$ of lactation and included calving difficulty, metritis, ketosis, and left displaced abomasum. Milk production and individual somatic cell scores (SCS) were recorded monthly by the Dairy Herd Improvement Association. The main outcome variables were the risk of clinical mastitis during the first 30 and $60 \mathrm{~d}$ of lactation, and the risk of subclinical mastitis at the first 2 monthly Dairy Herd Improvement Association tests after calving (up to $70 \mathrm{~d}$ in milk). Additionally, the SCS and the presence of mastitis pathogens in milk at dry-off and at calving were analyzed. Explanatory variables consisted of events occurring during the previous lactation, at dry-off and during the dry period, at calving, and within the first $30 \mathrm{~d}$ after calving. Multiple events occurring during the previous lactation had a significant effect on the incidence of mastitis in the subsequent lactation. These events included low milk yield, intermediate lactation length, clinical mastitis, and lactation SCS average. Similarly, intramammary infections with environmental bacteria at dry-off increased the chances of clinical mastitis the first month after calving. Dry-off
\end{abstract}

Received January 31, 2012.

Accepted August 12, 2012.

${ }^{1}$ Corresponding author: ppinedo@ag.tamu.edu therapy had a significant effect on mastitis incidence; cows treated with ceftiofur hydrochloride had lower odds of having clinical and subclinical mastitis in the subsequent early lactation compared with cows treated with penicillin dihydrostreptomycin.

Key words: mastitis, ceftiofur hydrochloride, penicillin dihydrostreptomycin, risk factor

\section{INTRODUCTION}

Mastitis represents an animal well-being concern and is the most costly disease to the dairy industry (Bar et al., 2008). Economic losses related to mastitis include reduced milk yield and quality (Schukken et al., 2011), higher replacement rates (Gröhn et al., 2005), and treatment costs (Bar et al., 2008). In addition, mastitis affects reproductive performance, resulting in increased days to first service, days open, services per conception (Moore et al., 1991; Barker et al., 1998), and a higher risk of abortion (Risco et al., 1999; Santos et al., 2004; Pinedo et al., 2009).

Mastitis causality is multi-factorial and contributing factors relate to individual cow characteristics, management, and environmental conditions (Barkema et al., 1999). Among others, predisposing factors significantly affecting mastitis incidence are the dry period length (Natzke et al., 1975; Rastani et al., 2005; Kuhn et al., 2007; Pinedo et al., 2011), previous SCC status (van den Borne et al., 2011), and milk yield (Newman et al., 2010).

The dry period represents a critical time in the production cycle where susceptibility to new IMI is highest (Oliver, 1988; Dingwell et al., 2003). However, this nonlactating time also provides the opportunity for extended intramammary antibiotic therapy to cure existing infections and to decrease the incidence of new infectious events at calving (Eberhart, 1986). Dry-cow therapy is regarded as one of the most important components of a mastitis control program, mainly because of a reduction in the number of staphylococcal and streptococcal infections (Whist et al., 2006). 
Penicillin dihydrostreptomycin (PD; Quartermaster; Pfizer Animal Health Inc., New York, NY) has been traditionally available for dry cow therapy and is recommended for intramammary use to reduce the prevalence of existing infections and to prevent new infections with Staphylococcus aureus in dry cows. Ceftiofur hydrochloride (CH; Spectramast DC; Pfizer Animal Health Inc.), more recently available, is indicated for the treatment of subclinical mastitis (SCM) associated with Staph. aureus, Streptococcus dysgalactiae, and Streptococcus uberis at the time of dry-off. Following intramammary infusion, milk from cows completing a 30-d Spectramast DC dry cow period may be used with no milk discard and to avoid potential ceftiofur residues in meat, a 16-d preslaughter withdrawal period is required. In contrast, following Quartermaster treatment, cows require a 42 - and $60-\mathrm{d}$ withdrawal period to avoid antibiotic residues in milk and meat, respectively. Thus, the shorter violative antibiotic residue avoidance periods for Spectramast DC are advantageous when considering choice of dry cow antibiotic therapy.

The efficacy of $\mathrm{CH}$ on both clinical and SCM treatment has been reported (Erskine et al., 2002; Oliver et al., 2004a,b; Wenz et al., 2005; Schukken et al., 2011). However, to our knowledge the use of $\mathrm{CH}$ intramammary treatment on the dry period has not been investigated outside of preapproval studies (Hallberg et al., 2006).

We hypothesized that the occurrence of early lactation mastitis would be influenced by the dry cow antibiotic therapy used and by mastitis events occurring during the previous lactation and the dry period, together with events occurring in the peripartum. Therefore, the objective of this randomized controlled trial was to investigate the association between mastitis events occurring during the previous lactation, the dry period, and peripartal events on the incidence of early lactation mastitis in cows receiving $\mathrm{CH}$ or $\mathrm{PD}$ as intramammary dry cow antibiotic therapy

\section{MATERIALS AND METHODS}

\section{Treatment Allocation, Sample Collection, and Data Compilation}

Cows originated from 2 large dairy farms in Central Florida were enrolled in the study at the time of dry-off processing. The dry-off procedures were performed on 1 farm and all cows remained at this farm until the next calving. Cows eligible for enrollment were in good general health, and had 4 functional quarters without significant teat lesions. Cows $(\mathrm{n}=402)$ were assigned to 1 of 2 dry cow therapies: CH (Spectramast DC; Pfizer Animal Health Inc.) or PD (Quartermaster; Pfizer
Animal Health Inc.) at the time of dry-off processing according to their position (odd or even milking unit number) in the 12-unit hospital milking parlor. Cows entered the milking parlor in groups, in a random manner that precluded herdsman selection for a particular cow position. The treatment allocation to odd or even milking unit number was switched every week. Cows receiving PD were considered the control group. During dry-off processing, 2 composite milk samples from the 4 quarters were collected by trained personnel following standard aseptic procedures (National Mastitis Council, 1999) that included teat-end disinfection with alcohol and disposal of the first streams of milk. Samples for bacteriological culture were frozen and samples for SCC were refrigerated after addition of potassium dichromate for subsequent submission to the Animal Health Diagnostic Center at the Quality Milk Production Center at Cornell University (Ithaca, NY). Following sample collection, the udders were milked and the corresponding intramammary infusion was applied according to label instructions by the manufacturer. A teat sealant (Orbeseal; Pfizer Animal Health Inc.) was applied to all quarters after antibiotic administration. Similarly, milk samples for bacteriological culture were obtained from a subset of the enrolled cows $(\mathrm{n}=179)$ at their third milking after calving. Due to logistic limitations, milk samples at calving from the complete enrolled population were not obtained. Nevertheless, no specific criterion was applied to select the subpopulation of cows sampled at that time point.

Milk production and SCS were recorded monthly by the DHIA. Clinical assessments for mastitis and peripartal health disorders were performed by farm personnel trained by the authors and by the farm veterinarian. Data regarding occurrence of these events [clinical mastitis (CM), metritis, ketosis, and left displaced abomasum)], and individual SCS during the first 2 DHI monthly test days were collected from farm software (PCDART Herd Manager, Dairy Herd Management Systems, Raleigh, NC). The occurrence of CM was defined at the cow level as an animal with at least one affected quarter and no distinction was made among cows with different numbers of quarters involved.

\section{Bacteriology}

All samples were submitted to the Animal Health Diagnostic Center at the Quality Milk Production Center at Cornell University. Approximately $0.1 \mathrm{~mL}$ of each milk sample was inoculated using cotton swabs on Trypticase soy agar plates containing $5 \%$ sheep blood and $0.1 \%$ esculin (bioMérieux Inc., Durham, NC) and incubated aerobically at $37^{\circ} \mathrm{C}$. Bacterial growth was identified after 24 and $48 \mathrm{~h}$ of incubation according 
to National Mastitis Council standards. Briefly, Staph. aureus and Staphylococcus spp. were identified by hemolytic pattern and tube coagulase test. Streptococcus dysgalactiae, Strep. uberis, and Streptococcus spp. were differentiated by presence or absence of esculin hydrolysis, Lancefield group C typing (PathoDx Strep grouping latex agglutination test; Remel Inc., Lenexa, KS), and growth or growth inhibition on bile esculin azide agar (Enterococcosel; Becton, Dickinson and Co., Franklin Lakes, NJ). Escherichia coli and Klebsiella spp. were identified using morphologic characteristics of colonies on MacConkey agar, production of indole, motility, and utilization of citrate.

\section{Variables of Interest}

Main outcome variables were the risk of $\mathrm{CM}$ during the first 30 and $60 \mathrm{~d}$ of lactation, and the risk of SCM at the first 2 monthly DHIA tests after calving (up to $70 \mathrm{~d}$ in lactation). Additionally, the SCS and the presence of mastitis pathogens in milk at dry-off and at calving were analyzed. The explanatory variables were grouped considering 3 periods: (1) previous lactation, (2) dry-off and dry period, and (3) calving and first $30 \mathrm{~d}$ after calving. Variables of interest for the previous lactation included length of lactation, occurrence of $\mathrm{CM}$ during the complete lactation and during the last $60 \mathrm{~d}$ of lactation, and lactation SCS average (grouped into categories $1=\mathrm{SCS}<4.5$ and $2=\mathrm{SCS}$ $\geq 4.5$ ). For all the analyses, SCS $\geq 4.5$ were considered an indication of SCM (Moore et al., 2005). The second group of variables included antibiotic treatment at dryoff (CH or PD), length of the dry period, SCM (SCS $\geq 4.5$ ), and milk bacteriological culture at dry-off. The analysis of bacteriological cultures considered different bacterial categorizations: (1) positive to any mastitis pathogen versus no growth, (2) gram-positive bacteria/ gram-negative bacteria/no growth, and (3) contagious bacteria/environmental bacteria/no growth. Variables considered as peripartal events were calving difficulty (scores: $1=$ no assistance to $3=$ significant assistance) and health events after calving (metritis, ketosis, and left displaced abomasum). For the analyses, all health events were considered together as a single binomial variable (peripartal health event: yes or no). Control variables were season of calving: winter (January to March), spring (April to June), summer (July to September), and fall (October to December); parity (1, 2, and $\geq 3$ ) ; and previous-lactation milk yield standardized to $305 \mathrm{~d}$ and mature cow basis (305ME).

The distribution of the continuous variables was examined through the use of histograms and descriptive statistics (e.g., means, medians, and SD) to assist in the subsequent categorization of the variables of interest and control variables. Continuous variables of interest were categorized as follows: length of the dry period: < $46 \mathrm{~d}$ (short), 46 to $75 \mathrm{~d}$ (intermediate), $>75 \mathrm{~d}$ (long); previous-lactation 305ME milk yield: $<9,583 \mathrm{~kg}$ (low), 9,584 to $11,773 \mathrm{~kg}$ (intermediate), and $>11,773$ $\mathrm{kg}$ (high); and length of the previous lactation: $<306 \mathrm{~d}$ (short), 306 to $463 \mathrm{~d}$ (intermediate), and $>463 \mathrm{~d}$ (long).

\section{Statistical Analysis}

Considering the delimited period at risk and the binary nature of the outcome variables, logistic regression was used for the analyses, and generalized linear models were fitted to the data. The appropriate randomization of cows at the time of enrollment for categorical outcomes (calving season, average SCS during the previous lactation, SCS at dry-off, mastitis-causing bacteria at dry-off, and parity) was analyzed by the chi-squared test (PROC FREQ; SAS Institute Inc., Cary, NC). The effect of the explanatory variables was evaluated by using the logit link (PROC GLIMMIX; SAS Institute Inc.). Univariate analyses were used to test the inclusion of each explanatory variable in the final models. Effects with a $P$-value $\leq 0.20$ were included in the multivariable analysis. The final models were tested through a backward elimination procedure. The significance level for inclusion in the final model was set at $P \leq 0.10$ to account for potential confounders affecting both the response and the predictors. Dry cow therapy was forced in the final models and interactions between the effect of treatment and significant variables were considered.

Time-to-event analyses were performed for CM occurrence. Hazard distributions for CM up to 60 DIM were calculated using the actuarial method of the LIFETEST procedure of SAS (release 9.2; SAS Institute Inc.) to test the null hypothesis that the survivor functions (time from calving to a CM event) were identical for the 2 groups receiving a different intramammary dry cow therapy. Additionally, a Cox proportional regression model was developed to evaluate the effect of multiple variables on the risk of CM during early lactation (PROC PHREG; SAS Institute Inc.). Statistical significance was set at $P \leq 0.05$.

\section{RESULTS}

\section{Descriptive Data}

Four hundred two cows were enrolled between $\mathrm{Au}-$ gust and November 2010 and had complete data for dry-off bacteriological culture and SCS (Spectramast DC: $\mathrm{n}=198$; Quartermaster: $\mathrm{n}=204$ ). Milk samples were also obtained from a subpopulation of 179 cows (Spectramast DC: $\mathrm{n}=90$; Quartermaster: $\mathrm{n}=89$ ) at 
the third milking after calving. The percentage of cows with an average SCS $\geq 4.5$ during the previous lactation was $9.8 \%$. The percentage of cows with at least 1 case of $\mathrm{CM}$ during the last $60 \mathrm{~d}$ and the complete previous lactation was 5.6 and $40 \%$, respectively. For the current lactation, the percentage of cows with SCM at the first, the second, and both DHI test days combined was 17.1, 16.1 , and $26.5 \%$, respectively. No significant associations between the treatment allocation and the distribution of cows by parity $(P=0.70)$, calving season $(P$ $=0.85)$, average SCS during the previous lactation $(P$ $=0.28), \mathrm{CM}$ occurrence in the previous lactation $(P=$ $0.61)$, mastitis-causing bacteria at dry-off $(P=0.16)$, and SCM at dry-off $(P=0.56)$ were found, indicating an appropriate randomization of individuals at the time of enrollment.

\section{Bacteriological Cultures}

Contamination was reported for 27 and 19 of the samples collected at dry-off and at calving, respectively. Isolates of mastitis-causing bacteria were obtained from $19.6 \%$ (402 cultures available) and $12.9 \%$ (179 cultures available) of the enrolled cows at dry-off and at calving, respectively. The main categories isolated at dry-off were Staph. aureus $(7.5 \%)$, Staphylococcus spp. (4.0\%), Bacillus spp. (2.7\%), coliform (2.2\%), and Streptococcus spp. (1.2\%). At calving, the main isolates were Staphylococcus spp. (5.6\%), Staph. aureus (3.4\%), and Streptococcus spp. (1.7\%; Table 1).

The univariate analyses indicated a significant effect on the presence of mastitis-causing bacteria at dry-off for $\mathrm{CM}$ during the last $60 \mathrm{~d}$ of the previous lactation [odds ratio $(\mathbf{O R})=2.90 ; 95 \% \mathrm{CI}=1.50-7.35]$, $\mathrm{SCM}$ at dry-off $(\mathrm{OR}=1.84 ; 95 \% \mathrm{CI}=1.03-3.27)$ and for herd (Table 2). The final multivariable model showed an effect for SCM at dry-off $(\mathrm{OR}=1.89 ; 95 \% \mathrm{CI}=$
1.05-3.40) and herd on the presence of mastitis-causing bacteria at dry-off (Table 3). According to the univariate analyses, the presence of mastitis-causing bacteria at calving was significantly affected by high SCS average in the previous lactation $(\mathrm{OR}=4.55 ; 95 \% \mathrm{CI}=$ $1.36-16.6)$, parity 1 versus $\geq 3(\mathrm{OR}=0.16 ; 95 \% \mathrm{CI}=$ $0.03-0.74)$, and parity 2 versus $\geq 3(\mathrm{OR}=0.33 ; 95 \%$ $\mathrm{CI}=0.11-0.96)$. In the final multivariable model, only the effect of high SCS average in the previous lactation remained significant $(\mathrm{OR}=6.60 ; 95 \% \mathrm{CI}=1.58-22.0)$ for the presence of mastitis-causing bacteria at calving. The effect of treatment (CH or PD) on the presence of mastitis-causing bacteria at calving was not significant $(P=0.32$; Table 3$)$.

\section{Within 30 d After Calving}

The incidence of $\mathrm{CM}$ at the cow level during the first $30 \mathrm{~d}$ after calving was $7.4 \%$. The univariate logistic regression indicated that the isolation of gram-negative bacteria at dry-off significantly increased the odds for $\mathrm{CM}$ occurrence up to $30 \mathrm{~d}$ after calving $(\mathrm{OR}=10.3$; $95 \% \mathrm{CI}=2.01-49.0)$ and this effect remained significant in the final multivariable model $(\mathrm{OR}=7.43 ; 95 \% \mathrm{CI}$ $=1.25-44.0)$. Other variables significantly affecting the incidence of CM were low milk yield and intermediate length of the previous lactation. Similarly, intermediate length of the dry period, parity, and season of calving were significant effects in the univariate analyses (Table 4).

The final model indicated significant effects for previous-lactation low milk yield $(\mathrm{OR}=4.21 ; 95 \% \mathrm{CI}=$ 1.29-13.7 for low vs. high) and intermediate compared with extended length of the previous lactation $(\mathrm{OR}=$ $10.9 ; 95 \% \mathrm{CI}=1.42-84.4)$. The effect of dry-off therapy was significant $(\mathrm{OR}=0.38 ; 95 \% \mathrm{CI}=0.15-0.98$ for $\mathrm{CH}$ compared with PD; Table 5).

Table 1. Distribution of the main bacteriological isolates found at dry-off and at calving by herd and dry-off therapy

\begin{tabular}{|c|c|c|c|c|c|}
\hline \multirow[b]{2}{*}{ Item } & \multicolumn{2}{|c|}{ Herd (n) } & \multicolumn{2}{|c|}{ Dry-off therapy $^{1}(\mathrm{n})$} & \multirow[b]{2}{*}{ Total $(\%)$} \\
\hline & $\mathrm{A}$ & $\mathrm{B}$ & $\mathrm{PD}$ & $\mathrm{CH}$ & \\
\hline \multicolumn{6}{|l|}{ Dry-off $(\mathrm{n}=402)$} \\
\hline Staphylococcus aureus & 16 & 14 & 14 & 16 & 7.46 \\
\hline Staphylococcus spp. & 10 & 6 & 7 & 9 & 3.98 \\
\hline Bacillus spp. & 7 & 4 & 6 & 5 & 2.74 \\
\hline Coliform & 7 & 2 & 4 & 5 & 2.24 \\
\hline Streptococcus spp. & 5 & 0 & 4 & 1 & 1.24 \\
\hline \multicolumn{6}{|l|}{ Calving $(\mathrm{n}=179)$} \\
\hline Staphylococcus spp. & 4 & 6 & 5 & 5 & 5.59 \\
\hline Staph. aureus & 2 & 4 & 4 & 2 & 3.35 \\
\hline Streptococcus spp. & 2 & 1 & 2 & 1 & 1.68 \\
\hline
\end{tabular}

${ }^{1} \mathrm{PD}=$ penicillin dihydrostreptomycin; $\mathrm{CH}=$ ceftiofur hydrochloride. 
Table 2. Unadjusted odds ratios $(\mathrm{OR})$ for risk of positive bacteriological culture in milk at dry-off and at calving ${ }^{1}$

\begin{tabular}{|c|c|c|c|c|c|c|}
\hline Variable & \multicolumn{3}{|c|}{ Dry-off } & \multicolumn{3}{|c|}{ Calving } \\
\hline Yes & - & - & - & 2.15 & $0.89-5.23$ & 0.08 \\
\hline No & - & - & - & - & - & - \\
\hline \multicolumn{7}{|c|}{ Clinical mastitis in last $60 \mathrm{~d}$ of previous lactation } \\
\hline Yes & 2.90 & $1.50-7.35$ & 0.02 & - & - & - \\
\hline \multicolumn{7}{|c|}{ Previous-lactation SCS average } \\
\hline$\geq 4.5$ & 1.96 & $0.89-4.33$ & 0.09 & 4.55 & $1.36-16.6$ & 0.01 \\
\hline$<4.5$ & - & - & - & - & - & - \\
\hline \multicolumn{7}{|c|}{ Subclinical mastitis at dry-off } \\
\hline Yes & 1.84 & $1.03-3.27$ & 0.03 & - & - & - \\
\hline No & - & - & - & - & - & - \\
\hline \multicolumn{7}{|l|}{ Parity } \\
\hline 1 & - & - & - & 0.16 & $0.03-0.74$ & 0.01 \\
\hline
\end{tabular}

${ }^{1}$ Only effects with $P \leq 0.1$ are presented.

\section{Within 60 d After Calving}

The incidence of $\mathrm{CM}$ at the cow level during the first $60 \mathrm{~d}$ after calving was $10.1 \%$. According to the univariate analysis, this value was significantly affected by the isolation of environmental bacteria at dry-off $(\mathrm{OR}=$ $2.74 ; 95 \%$ CI $=1.06-7.07$ for environmental bacteria vs. no growth). Other significant effects were low milk yield, CM, and high SCS average in the previous lactation. Similarly, type of treatment at dry-off, length of the dry period, parity, season of calving, and peripartal health event were significant effects in the univariate analyses (Table 4).

The final logistic regression model indicated significant effects for previous-lactation low milk yield $(\mathrm{OR}=$
$5.10 ; 95 \% \mathrm{CI}=2.09-12.4), \mathrm{CM}$ in the last $60 \mathrm{~d}$ of the previous lactation $(\mathrm{OR}=4.11 ; 95 \% \mathrm{CI}=1.32-12.8)$, high SCS average in the previous lactation $(\mathrm{OR}=2.94$; $95 \% \mathrm{CI}=1.15-7.51)$, and season of calving ( $\mathrm{OR}=$ 2.34; $95 \% \mathrm{CI}=1.06-5.18$ for winter vs. fall). The effect of dry-off therapy was significant $(\mathrm{OR}=0.27 ; 95 \%$ CI $=0.13-0.58$ for $\mathrm{CH}$ vs. PD; Table 5 ).

Consistency between the logistic regression and the Cox hazard regression model was observed for most of the variables, except for season of calving, which resulted slightly above the significance level limit in the hazard regression model $(P=0.052$ for winter vs. fall). Results from the Cox proportional hazard model indicated that the highest risk of suffering CM was associated with low milk yield during the previous lacta-

Table 3. Final logistic regression model for risk of positive bacteriological culture in milk at dry-off and at calving

\begin{tabular}{|c|c|c|c|c|c|c|}
\hline Variable & \multicolumn{3}{|c|}{ Dry-off } & \multicolumn{3}{|c|}{ Calving } \\
\hline \multicolumn{7}{|l|}{ Previous-lactation SCS average } \\
\hline$<4.5$ & - & - & - & - & - & - \\
\hline \multicolumn{7}{|l|}{ Dry-off therapy } \\
\hline Ceftiofur hydrochloride & $\mathrm{NA}^{2}$ & NA & NA & 0.61 & $0.22-1.64$ & 0.32 \\
\hline Yes & 1.89 & $1.05-3.40$ & 0.03 & - & - & - \\
\hline No & - & - & - & - & - & - \\
\hline \multicolumn{7}{|l|}{ Herd } \\
\hline $\mathrm{A}$ & 1.98 & $1.11-3.57$ & 0.02 & - & - & - \\
\hline $\mathrm{B}$ & - & - & - & - & - & - \\
\hline
\end{tabular}

${ }^{1}$ Odds ratio.

${ }^{2} \mathrm{NA}=$ not applicable. 
Table 4. Unadjusted odds ratios (OR) for risk of clinical mastitis during the first 30 and $60 \mathrm{~d}$ after calving ${ }^{1}$

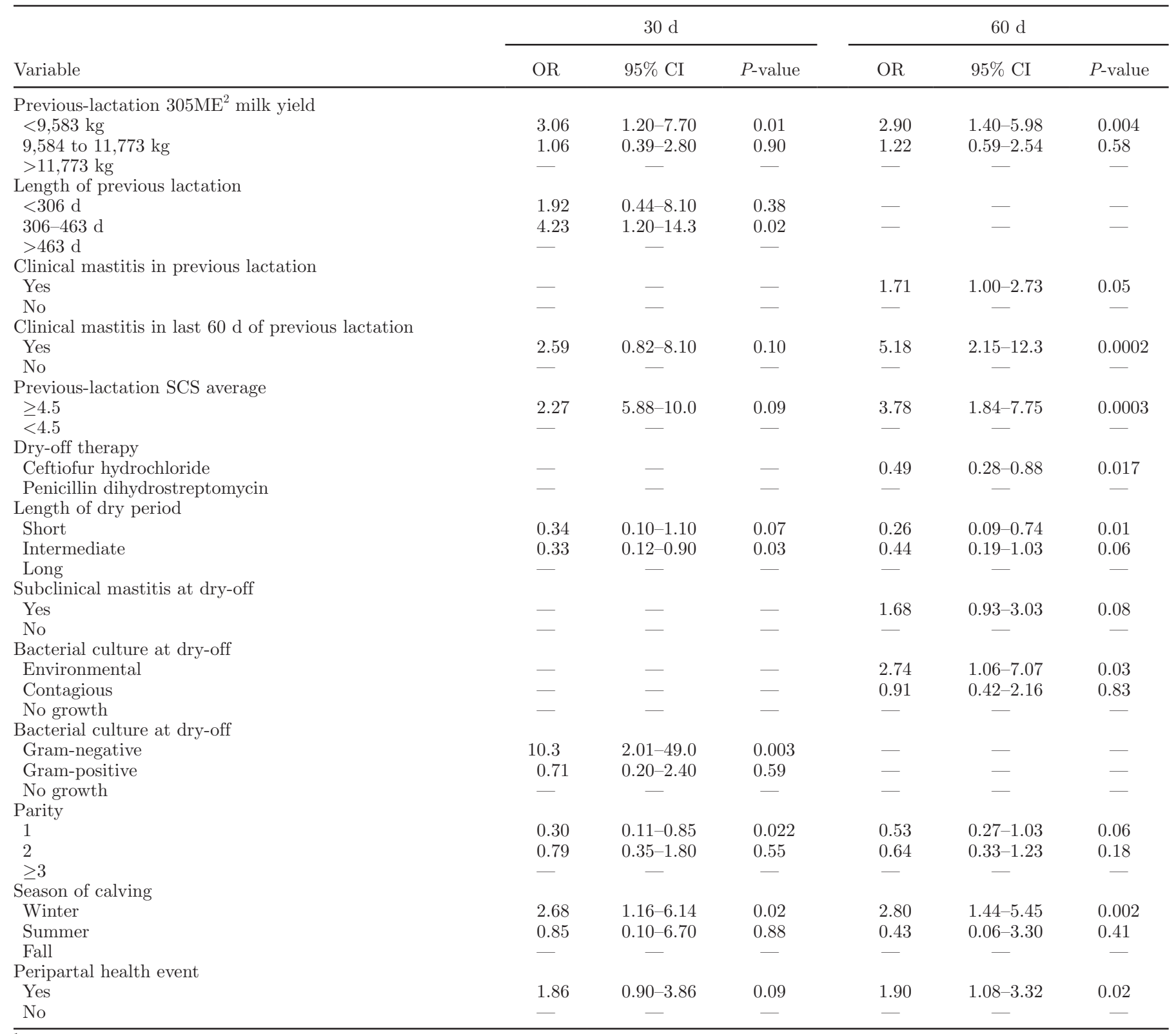

${ }^{1}$ Only effects with $P \leq 0.1$ are presented.

${ }^{2}$ Milk yield standardized to $305 \mathrm{~d}$ and mature cow basis.

tion [hazard ratio $(\mathbf{H R})=2.95], \mathrm{CM}$ in the last $60 \mathrm{~d}$ of the previous lactation ( $\mathrm{HR}=2.65)$, and high SCS average in the previous lactation $(\mathrm{HR}=2.20)$. The use of $\mathrm{CH}$ as intramammary dry cow antibiotic therapy was associated with a lower risk of CM when compared with PD $(\mathrm{HR}=0.44$; Table 6$)$.

Figure 1 shows the survival curves for the interval from calving to the first case of CM by dry cow therapy. The analysis indicated a tendency on the effect of treatment on time to $\mathrm{CM}(P=0.10)$.

\section{SCM Within 30 d After Calving}

The prevalence of SCM at the first test day after calving was $17.1 \%$. The univariate logistic regression indicated that the odds for SCM occurrence up to 30 $\mathrm{d}$ after calving were significantly affected by $\mathrm{CM}, \mathrm{CM}$ during the last $60 \mathrm{~d}$, and high SCS average in the previous lactation. Likewise, SCM at dry-off, length of the dry period, parity, and herd were significant effects in the univariate analyses (Table 7). 
Table 5. Final logistic regression model for risk of clinical mastitis during the first 30 and $60 \mathrm{~d}$ postcalving by treatment group, subclinical mastitis status, and bacterial culture status at dry-off and farm ${ }^{1}$

\begin{tabular}{|c|c|c|c|c|c|c|}
\hline \multirow[b]{2}{*}{ Variable } & \multicolumn{3}{|c|}{$30 \mathrm{~d}$} & \multicolumn{3}{|c|}{$60 \mathrm{~d}$} \\
\hline & $\mathrm{OR}^{2}$ & $95 \% \mathrm{CI}$ & $P$-value & OR & $95 \% \mathrm{CI}$ & $P$-value \\
\hline \multicolumn{7}{|c|}{ Previous-lactation $305 \mathrm{ME}^{3}$ milk yield } \\
\hline$<9,583 \mathrm{~kg}$ & 4.21 & $1.29-13.7$ & 0.01 & 5.10 & $2.09-12.4$ & 0.0003 \\
\hline 9,584 to $11,773 \mathrm{~kg}$ & 0.95 & $0.26-3.53$ & 0.94 & 1.55 & $0.63-3.85$ & 0.34 \\
\hline$>11,773 \mathrm{~kg}$ & - & - & - & - & - & - \\
\hline \multicolumn{7}{|l|}{ Length of previous lactation } \\
\hline$\geq 464 \mathrm{~d}$ & - & - & - & - & - & - \\
\hline \multicolumn{7}{|c|}{ Clinical mastitis in last $60 \mathrm{~d}$ of previous lactation } \\
\hline Yes & - & - & - & 4.11 & $1.32-12.8$ & 0.01 \\
\hline No & - & - & - & - & - & - \\
\hline \multicolumn{7}{|l|}{ Previous-lactation SCS average } \\
\hline$\geq 4.5$ & - & - & - & 2.94 & $1.15-7.51$ & 0.02 \\
\hline$<4.5$ & - & - & - & - & - & - \\
\hline Gram-positive & 0.81 & $0.22-3.02$ & 0.76 & - & - & - \\
\hline No growth & - & - & - & - & - & - \\
\hline \multicolumn{7}{|l|}{ Season of calving } \\
\hline Winter & - & - & - & 2.34 & $1.06-5.18$ & 0.03 \\
\hline Summer & - & - & - & 0.35 & $0.04-3.03$ & 0.33 \\
\hline Fall & - & - & - & - & - & - \\
\hline
\end{tabular}

${ }^{1}$ Only effects with $P \leq 0.1$ are presented.

${ }^{2}$ Odds ratio.

${ }^{3}$ Milk yield standardized to $305 \mathrm{~d}$ and mature cow basis.

The final model indicated significant effects for previous-lactation low milk yield $(\mathrm{OR}=2.37 ; 95 \% \mathrm{CI}$ $=1.09-5.15$ for low vs. high), $\mathrm{CM}$ in the last $60 \mathrm{~d}$ of the previous lactation $(\mathrm{OR}=4.78 ; 95 \% \mathrm{CI}=1.67-13.6)$, and previous-lactation high SCS average $(\mathrm{OR}=4.80$; $95 \% \mathrm{CI}=2.08-11.1)$. The effect of dry-off therapy was significant $(\mathrm{OR}=0.51 ; 95 \% \mathrm{CI}=0.27-0.97$ for $\mathrm{CH}$ vs. PD; Table 8).

Table 6. Cox hazard regression model for the risk of clinical mastitis during the first $60 \mathrm{~d}$ postcalving

\begin{tabular}{|c|c|c|c|}
\hline Variable & $\mathrm{HR}^{1}$ & $95 \% \mathrm{CI}$ & $P$-value \\
\hline \multicolumn{4}{|c|}{ Previous-lactation $305 \mathrm{ME}^{2}$ milk yield } \\
\hline$<9,583 \mathrm{~kg}$ & 2.95 & $1.35-6.44$ & 0.006 \\
\hline 9,584 to $11,773 \mathrm{~kg}$ & 1.51 & $0.68-3.29$ & 0.30 \\
\hline$>11,773 \mathrm{~kg}$ & - & - & - \\
\hline \multicolumn{4}{|c|}{ Clinical mastitis in last $60 \mathrm{~d}$ of previous lactation } \\
\hline Yes & 2.65 & $1.04-6.75$ & 0.04 \\
\hline No & - & - & - \\
\hline \multicolumn{4}{|l|}{ Previous-lactation SCS average } \\
\hline$\geq 4.5$ & 2.20 & $1.03-4.71$ & 0.04 \\
\hline$<4.5$ & - & - & - \\
\hline \multicolumn{4}{|l|}{ Dry-off therapy } \\
\hline Penicillin dihydrostreptomycin & 0.44 & $0.24-0.83$ & 0.009 \\
\hline Ceftiofur hydrochloride & - & - & - \\
\hline \multicolumn{4}{|l|}{ Season of calving } \\
\hline Winter & 1.94 & $0.99-3.82$ & 0.052 \\
\hline Summer & 0.53 & $0.07-4.00$ & 0.54 \\
\hline Fall & - & - & - \\
\hline
\end{tabular}

${ }^{1}$ Hazard ratio

${ }^{2}$ Milk yield standardized to $305 \mathrm{~d}$ and mature cow basis. 


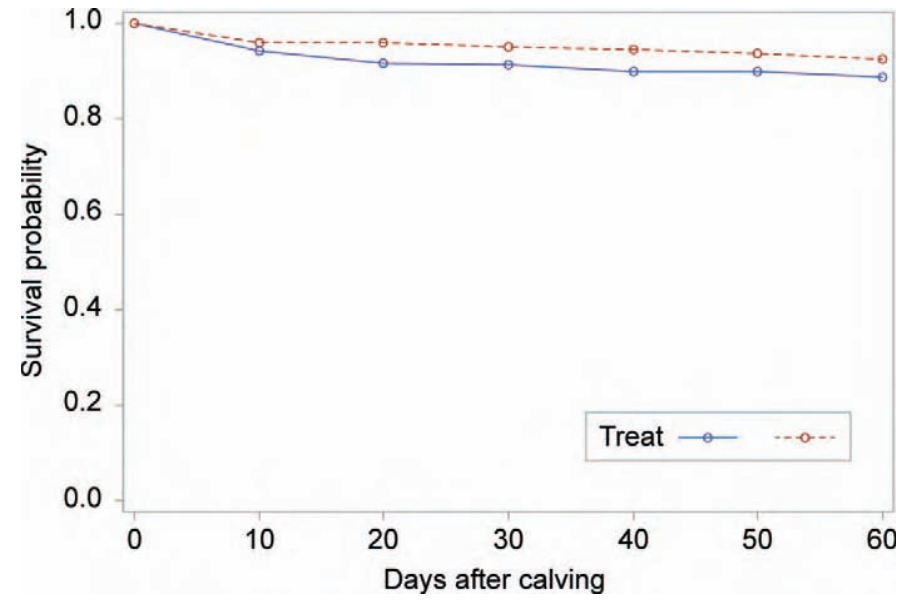

Figure 1. Survival curves for the interval from calving to the first case of clinical mastitis by type of dry cow therapy $(P=0.10)$. Treat $=$ treatment; $0=$ penicillin dihydrostreptomycin $(-\mathrm{O}-) ; 1=$ ceftiofur hydrochloride (- - $\bigcirc-$ - ). Color version available in the online PDF.

\section{SCM Within 60 d After Calving}

The prevalence of SCM at the second test day after calving was $16.1 \%$. When the data from both test days were combined, $26.5 \%$ of the enrolled cows had been affected by SCM since calving. The univariate logistic regression indicated that the odds for SCM occurrence up to $60 \mathrm{~d}$ after calving were significantly affected by $\mathrm{CM}$, CM during the last $60 \mathrm{~d}$, and high SCS average in the previous lactation. Similarly, SCM at dry-off, parity, peripartal health event, and herd were significant effects in the univariate analyses (Table 7).

The final model indicated significant effects for CM in the last $60 \mathrm{~d}$ of the previous lactation $(\mathrm{OR}=3.18$; $95 \%$ CI $=1.07-9.43)$, previous-lactation SCS average $(\mathrm{OR}=6.08 ; 95 \% \mathrm{CI}=2.56-14.4)$, peripartal health event $(\mathrm{OR}=1.99 ; 95 \% \mathrm{CI}=1.18-3.36)$, and herd. A significant effect for treatment was observed on the incidence of SCM during the first 2 test days after calv-

Table 7. Unadjusted odds ratios (OR) for risk of subclinical mastitis during the first 30 and $60 \mathrm{~d}$ after calving

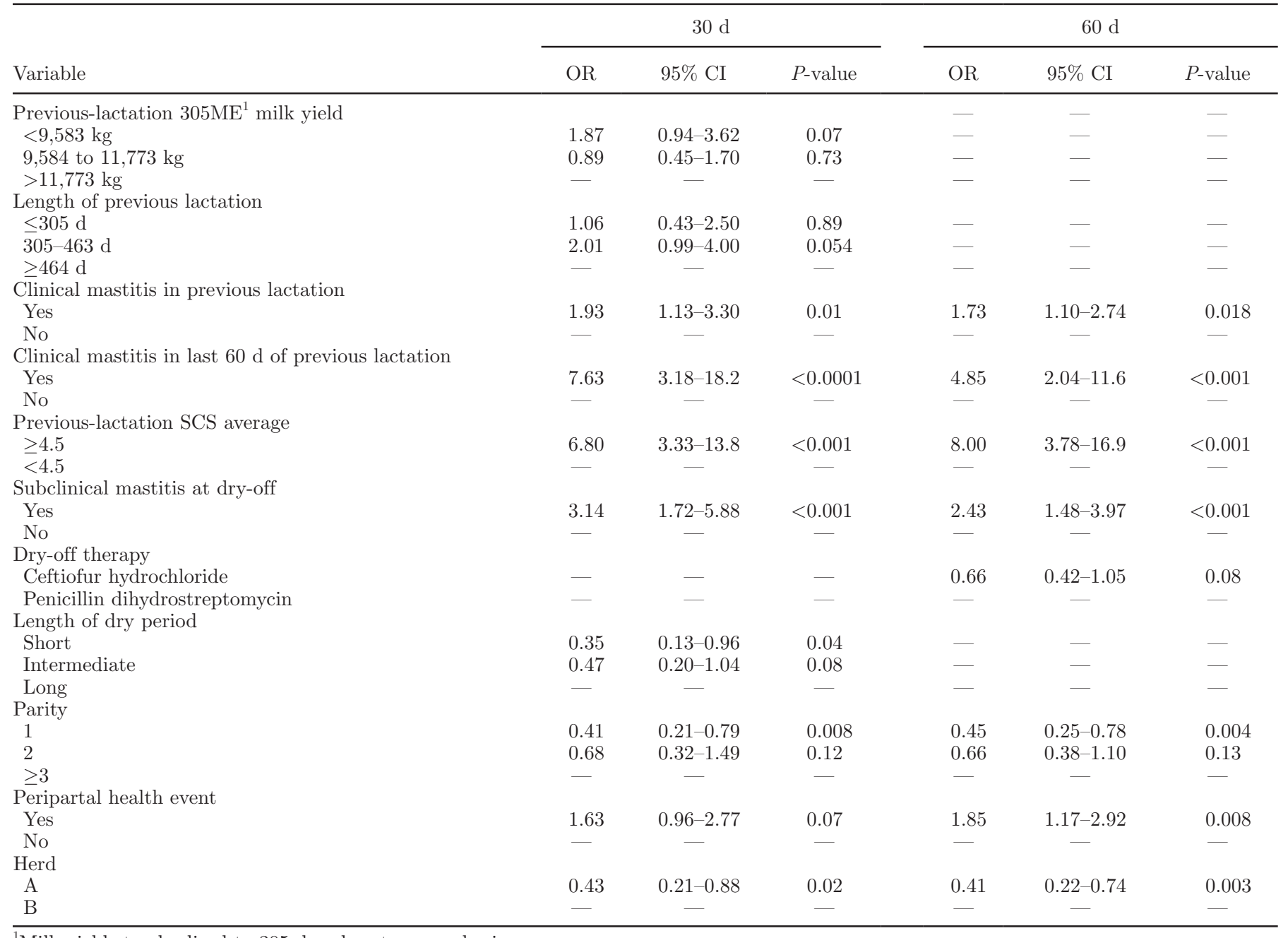

${ }^{1}$ Milk yield standardized to $305 \mathrm{~d}$ and mature cow basis. 
Table 8. Final logistic regression model for risk of subclinical mastitis during the first 30 and 60 d postcalving

\begin{tabular}{|c|c|c|c|c|c|c|}
\hline Variable & \multicolumn{3}{|c|}{$30 \mathrm{~d}$} & \multicolumn{3}{|c|}{$60 \mathrm{~d}$} \\
\hline \multicolumn{7}{|c|}{ Previous-lactation $305 \mathrm{ME}^{2}$ milk yield } \\
\hline 9,584 to $11,773 \mathrm{~kg}$ & 0.89 & $0.41-1.95$ & 0.78 & - & - & - \\
\hline$>11,773 \mathrm{~kg}$ & - & - & - & & & \\
\hline \multicolumn{7}{|c|}{ Clinical mastitis in last $60 \mathrm{~d}$ of previous lactation } \\
\hline \multicolumn{7}{|l|}{ Previous-lactation SCS average } \\
\hline$\geq 4.5$ & 4.80 & $2.08-11.1$ & 0.0003 & 6.08 & $2.56-14.4$ & $<0.0001$ \\
\hline$<4.5$ & - & - & - & - & - & - \\
\hline \multicolumn{7}{|l|}{ Dry-off therapy } \\
\hline Ceftiofur hydrochloride & 0.51 & $0.27-0.97$ & 0.04 & 0.52 & $0.30-0.90$ & 0.01 \\
\hline Penicillin dihydrostreptomycin & - & - & - & - & - & - \\
\hline \multicolumn{7}{|l|}{ Peripartal health event } \\
\hline
\end{tabular}

ing $(\mathrm{OR}=0.52 ; 95 \% \mathrm{CI}=0.30-0.90$ for $\mathrm{CH}$ vs. $\mathrm{PD}$; Table 8).

\section{DISCUSSION}

This study used composite milk samples in which milk from all 4 quarters was collected in a single vial. Composite samples have been shown to have lower sensitivity but similar specificity in pathogen culture when compared with individual quarter milk samples (Lam et al., 1996; Reyher and Dohoo, 2011). On the other hand, the risk for contamination with environmental bacteria increases when composite samples are collected. The prevalence of IMI at dry-off and at postcalving was 19.2 and $12.9 \%$, respectively. These prevalence values are similar to those reported in other studies analyzing quarter milk samples (Pantoja et al., 2009a,b); however, the distribution of the diverse populations of isolates at dry-off differed from frequencies reported previously. Staphylococcus aureus was the main pathogen isolated in this study (7.5\%), followed by Staphylococcus spp. (4.0\%) and Bacillus spp. (2.7\%). Some studies (Godden et al., 2003; Cook et al., 2005; Pantoja et al., 2009a,b) presented CNS as the most prevalent pathogens causing IMI at dry-off. However, the proportion of specific pathogens causing new IMI during the dry period has varied among studies (Dingwell et al., 2002; Godden et al., 2003; Cook et al., 2005). The effect of freezing on the qualitative results of bacteriologic culturing of milk collected from cows with clinical or subclinical IMI has been reported (Schukken et al., 1989; Sol, et al., 2002) and this factor may have affected the proportion of gram-positive and gram-negative bacteria isolated in this study. The presence of mastitis causing bacteria at dry-off was significantly affected by CM during the last $60 \mathrm{~d}$ of the previous lactation and by SCM at dry-off. Similarly, high SCS average in the previous lactation was associated to a higher probability of mastitiscausing bacteria at calving, which is in agreement with previous reports (Pantoja et al., 2009b).

Due to logistic limitations, only a subpopulation (n $=179$ ) of the enrolled cows could be sampled after calving. Consequently, the scope of the results on the effect of the treatment on IMI at calving is limited. Our main pathogens at postcalving were Staphylococcus spp. (5.6\%), Staph. aureus (3.4\%), and Streptococcus spp. (1.7\%). In contrast, Dingwell et al. (2002) and Godden et al. (2003) found a greater proportion of new IMI present at postcalving sampling periods caused by environmental streptococci than IMI caused by CNS, and Green et al. (2005) reported that E. coli were isolated from $12 \%$ of all quarters sampled during the late dry to calving period.

In the current study, cows with lower milk production in the previous lactation had higher odds of CM and SCM up to $30 \mathrm{~d}$ after calving compared with highproducing cows. This is in disagreement with information presented by Suriyasathaporn et al. (2000), who reported that the odds of presenting CM increased with an increase in milk yield. A possible explanation is that in the study by Suriyasathaporn et al. (2000), the measurements were concurrent with the mastitis 
event. In our case, the estimated milk yield originated from the previous lactation and could be an indication of suboptimal mammary health.

Mastitis events occurring during the previous lactation had a significant effect on both CM and SCM in the subsequent lactation. Clinical mastitis and high average SCS in the previous lactation increased the odds of CM up to $60 \mathrm{~d}$ after calving and also had a significant detrimental effect on SCM at 30 and $60 \mathrm{~d}$. These associations have been presented previously; Pantoja et al. (2009b) reported that quarters that had at least 1 case of mastitis during the previous lactation were 4.2 times more likely to have a first case of $\mathrm{CM}$ in the subsequent lactation than quarters that did not have CM in the previous lactation. Similarly, Green et al. (2007) reported that 1 or more case of SCC $>199,000$ cells/ $\mathrm{mL}$ within $90 \mathrm{~d}$ before drying off increased the odds of CM within $30 \mathrm{~d}$ of calving. van den Borne et al. (2011) described that first-parity cows with a high composite SCC had a 4-fold higher hazard for subsequent CM than cows with a low SCC; multiparae with a high composite SCC had a 2-fold higher hazard than multiparae with a low composite SCC. Additionally, multiparae with a low SCC had a 2-fold higher hazard for CM occurrence than primiparae with a low SCC. In another study, cows with $\mathrm{SCC} \geq 200,000$ cells $/ \mathrm{mL}$ across the dry period had a greater risk of being subclinically infected by a major pathogen at the first DHI test than cows with SCC $<200,000$ cells/mL (Pantoja et al., 2009a). Quarters with SCC $\geq 200,000$ cells/mL at both dry-off and postcalving sampling periods were 20.4 times more likely to be subclinically infected by a major pathogen and 5.6 times more likely to be subclinically infected by a minor pathogen at the first DHI test than quarters with SCC $<200,000$ cells $/ \mathrm{mL}$ at both periods (Pantoja et al., 2009a). Similarly, quarters with SCC $\geq 200,000$ cells $/ \mathrm{mL}$ at dry-off and postcalving were 2.7 times more likely to experience a first case of mastitis than quarters with SCC $<200,000$ cells $/ \mathrm{mL}$ at both periods (Pantoja et al., 2009a). Likewise, cows with a geometric mean of the 3 last SCC test days between 50,000 and 100,000 cells/mL and between 401,000 and 800,000 cells/mL in the first lactation had HR of CM during the second lactation of 1.3 and 2.8, respectively, compared with a reference group of 10,000 to 20,000 cells $/ \mathrm{mL}$. If a CM episode in the first lactation occurred, the HR for a CM event during the second lactation was 1.5 (Whist and Osterås, 2007).

The effect of dry period length on new IMI has been reported. Cows with extended dry period (143 to 250 d) had higher odds of SCM compared with cows with a conventional dry period (53 to $76 \mathrm{~d}$; Pinedo et al., 2009). On the other hand, reduced dry periods were associated to a lower number of new IMI (Natzke et al.,
1975; Rastani et al., 2005), had no effect (Church et al., 2008; Watters et al., 2008), or had a detrimental influence on SCS (Kuhn et al., 2007). In the current study, the final models indicated no effect for the length of the dry period on IMI. It is presumable that differences on the length of the dry period require a larger population for evidencing significant effects.

Increasing parity has been reported to be a risk factor for new dry period infections, suggesting that anatomical or intramammary defense mechanisms of cows may deteriorate with age (Zadoks et al., 2001; Green et al., 2002; Dingwell et al., 2004). Our results in the univariate models are consistent with this information. However, probably due to correlation with other variables, in the final models this effect was not significant.

It has been documented that IMI present in the dry period will result in clinical disease in lactation (McDonald and Anderson, 1981; Bradley and Green, 2001; Zadoks et al., 2001). The univariate analyses in the current study indicated that the presence of environmental pathogens in milk at dry-off increased the chances of $\mathrm{CM}$ in the first $60 \mathrm{~d}$ of lactation $(\mathrm{OR}=2.74)$. Gramnegative bacteria increased the chances of $\mathrm{CM}$ in the first $30 \mathrm{~d}$ of lactation $(\mathrm{OR}=10.3)$. The final model suggested that the presence of gram-negative bacteria in milk at dry-off increased the chances of $\mathrm{CM}$ in the first $30 \mathrm{~d}$ of lactation $(\mathrm{OR}=7.4)$. Even though our study considered a 1-point composite sample at dry-off, our findings are in agreement with those presented by Green et al. (2002), reporting that 38\% of CM cases that occurred in the subsequent lactation were caused by pathogens that had been previously isolated from serial milk samples collected from individual quarters during the dry period or at dry-off. The probability of CM occurrence increased when Strep. dysgalactiae, Streptococcus fecalis, E. coli, or Enterobacter spp. were present at dry-off and when E. coli, coagulasepositive staphylococci, Serratia spp., or Strep. fecalis were cultured in 2 out of 3 late dry and postcalving samples. Quarters from which Corynebacterium spp. were isolated at drying off were at an increased risk of CM. Similarly, approximately $45 \%$ of clinical cases that developed in the first $100 \mathrm{~d}$ of the following lactation were enterobacterial infections, of which $53 \%$ had been previously isolated during the dry period (Bradley and Green, 2000).

Peripartal disease has been reported to affect CM occurrence. Our final model indicated a significant effect of peripartal diseases on the occurrence of SCM before $60 \mathrm{~d}$ after calving $(\mathrm{OR}=1.99)$. Previous studies have reported the effect of health events on mastitis. Retained placenta (Schukken et al., 1988) and milk fever were associated with increased odds of getting CM. Cows with retained placenta had a 4-times higher 
risk to have CM, and OR for milk fever cows was 3.88 (Suriyasathaporn et al., 2000).

A central aim of the present study was to compare the efficacy of dry cow therapies with different duration of antibiotic residues in milk and meat after treatment. The efficacy of intramammary infusion of $\mathrm{CH}$ for the treatment of IMI has been reported. Oliver et al. (2004a,b) indicated that intramammary infusion of $125 \mathrm{mg}$ of $\mathrm{CH}$ into mammary quarters of lactating cows with SCM and CM was effective in eliminating infections caused by different mastitis pathogens, including Staph. aureus, Strep. dysgalactiae, CNS, and Corynebacterium bovis. The cure rate for an 8-d extended ceftiofur treatment regimen was $70 \%$ for $C$. bovis, $86 \%$ for CNS, $36 \%$ for Staph. aureus, $80 \%$ for Streptococcus dysgalactiae ssp. dysgalactiae, and $67 \%$ for Strep. uberis (Oliver et al., 2004a). The efficacy of intramammary treatment with $\mathrm{CH}$ of non-severe, clinical coliform mastitis was reported. Treatment consisted of $\mathrm{CH}$ via intramammary infusion at 24 -h intervals for $5 \mathrm{~d}$. Treated animals had a significant increase in bacteriological cure compared with nontreated controls. Treated animals clinically improved significantly more and remain longer in the herd compared with control cows (Schukken et al., 2011).

However, to our knowledge, the efficacy of intramammary infusion of $\mathrm{CH}$ for the treatment of IMI at dry-off and for prevention of new IMI during the dry period has not been investigated outside of preapproval studies. A dose of $125 \mathrm{mg}$ of ceftiofur per mammary quarter was effective for treatment of existing infections at dryoff, but only a 500-mg dose of ceftiofur per quarter was effective both for treatment of existing IMI and for prevention of new IMI during the dry period (Hallberg et al., 2006). Results from the present study indicate that, under the particular conditions of this study population, the use of different dry-off antibiotic therapy had a significant effect on mastitis incidence during the subsequent lactation. The final models showed that the use of $\mathrm{CH}$ as dry cow antibiotic therapy was associated with a lower incidence of $\mathrm{CM}$ during the first 30 and $60 \mathrm{~d}$ after calving compared with $\mathrm{PD}(\mathrm{OR}=0.38$ and 0.27 , respectively). Similarly, the use of $\mathrm{CH}$ as dry cow antibiotic therapy resulted in a lower incidence of SCM during the first 30 and $60 \mathrm{~d}$ after calving compared with $\mathrm{PD}(\mathrm{OR}=0.51$ and 0.52 , respectively $)$.

\section{CONCLUSIONS}

Multiple events occurring during the previous lactation had a significant effect on the incidence of mastitis in the subsequent lactation. These events included milk yield, lactation length, CM, and SCS average. Similarly,
IMI with environmental bacteria at dry-off increased the chances of CM the first month after calving. Dry-off antibiotic therapy had a significant effect on mastitis incidence; cows treated with $\mathrm{CH}$ had lower odds of being affected by CM and SCM in the subsequent early lactation compared with cows treated with PD.

\section{REFERENCES}

Bar, D., L. W. Tauer, G. Bennett, R. N. González, J. A. Hertl, Y. H. Schukken, H. F. Schulte, F. L. Welcome, and Y. T. Gröhn. 2008. The cost of generic clinical mastitis in dairy cows as estimated by using dynamic programming. J. Dairy Sci. 91:2205-2214.

Barkema, H. W., Y. H. Schukken, T. J. G. M. Lam, M. L. Beiboer, G. Benedictus, and A. Brand. 1999. Management practices associated with the incidence rate of clinical mastitis. J. Dairy Sci. 82:1643-1654.

Barker, A. R., F. N. Schrick, M. J. Lewis, H. H. Dowlen, and S. P. Oliver. 1998. Influence of clinical mastitis during early lactation on reproductive performance of Jersey cows. J. Dairy Sci. 81:1285-1290.

Bradley, A. J., and M. J. Green. 2000. A study of the incidence and significance of intramammary enterobacterial infections acquired during the dry period. J. Dairy Sci. 83:1957-1965.

Bradley, A. J., and M. J. Green. 2001. Clinical mastitis in a cohort of Somerset dairy herds. Vet. Rec. 148:683-686.

Church, G. T., L. K. Fox, C. T. Gaskins, D. D. Hancock, and J. M. Gay. 2008. The effect of a shortened dry period on intramammary infections during the subsequent lactation. J. Dairy Sci. 91:4219-4225.

Cook, N. B., D. A. Pionek, and P. Sharp. 2005. An assessment of the benefits of Orbeseal when used in combination with dry cow antibiotic therapy in three commercial dairy herds. Bovine Pract. 39:83-94.

Dingwell, R. T., T. F. Duffield, K. E. Leslie, G. P. Keefe, L. DesCoteaux, D. F. Kelton, K. D. Lissemore, Y. H. Schukken, P. Dick, and R. Bagg. 2002. The efficacy of intramammary tilmicosin at dryingoff, and other risk factors for the prevention of new intramammary infections during the dry period. J. Dairy Sci. 85:3250-3259.

Dingwell, R. T., D. F. Kelton, and K. E. Leslie. 2003. Management of the dry cow in control of peripartum disease and mastitis. Vet. Clin. North Am. Food Anim. Pract. 19:235-265.

Dingwell, R. T., K. E. Leslie, Y. H. Schukken, J. M. Sargeant, L. L. Timms, T. F. Duffield, G. P. Keefe, D. F. Kelton, K. D. Lissemore, and J. Conklin. 2004. Association of cow and quarter-level factors at drying-off with new intramammary infection during the dry period. Prev. Vet. Med. 63:75-89.

Eberhart, R. J. 1986. Management of dry cows to reduce mastitis. J. Dairy Sci. 69:1721-1732.

Erskine, R. J., P. C. Bartlett, J. L. VanLente, and C. R. Phipps. 2002. Efficacy of systemic ceftiofur as a therapy for severe clinical mastitis in dairy cattle. J. Dairy Sci. 85:2571-2575.

Godden, S., P. Rapnicki, S. Stewart, J. Fetrow, A. Johnson, R. Bey, and R. Farnsworth. 2003. Effectiveness of internal teat seal in the prevention of new intramammary infections during the dry and early-lactation periods in dairy cows when used with a dry cow intramammary antibiotic. J. Dairy Sci. 86:3899-3911.

Green, M. J., A. J. Bradley, G. F. Medley, and W. J. Browne. 2007. Cow, farm, and management factors during the dry period that determine the rate of clinical mastitis after calving. J. Dairy Sci. 90:3764-3776.

Green, M. J., L. E. Green, A. J. Bradley, P. R. Burton, Y. H. Schukken, and G. F. Medley. 2005. Prevalence and associations between bacterial isolates from dry mammary glands of dairy cows. Vet. Rec. 156:71-77.

Green, M. J., L. E. Green, G. F. Medley, Y. H. Schukken, and A. J. Bradley. 2002. Influence of dry period bacterial intramammary 
infection on clinical mastitis in dairy cows. J. Dairy Sci. 85:25892599.

Gröhn, Y. T., R. N. González, D. J. Wilson, J. A. Hertl, G. Bennett, H. Schulte, and Y. H. Schukken. 2005. Effect of pathogen-specific clinical mastitis on herd life in two New York State dairy herds. Prev. Vet. Med. 71:105-125.

Hallberg, J. W., M. Wachowski, W. M. Moseley, K. J. Dame, J. Meyer, and S. L. Wood. 2006. Efficacy of intramammary infusion of ceftiofur hydrochloride at drying off for treatment and prevention of bovine mastitis during the nonlactating period. Vet. Ther. 7:35-42.

Kuhn, M. T., J. L. Hutchison, and H. D. Norman. 2007. Dry period length in US Jerseys: Characterization and effects on performance. J. Dairy Sci. 90:2069-2081.

Lam, T. J., L. A. van Wuijckhuise, P. Franken, M. L. Morselt, E. G. Hartman, and Y. H. Schukken. 1996. Use of composite milk samples for diagnosis of Staphylococcus aureus mastitis in dairy cattle. J. Am. Vet. Med. Assoc. 208:1705-1708.

McDonald, J. S., and A. J. Anderson. 1981. Experimental intramammary infection of the dairy cow with Escherichia coli during the nonlactating period . Am. J. Vet. Res. 42:229-231.

Moore, D. A., J. S. Cullor, R. H. Bondurant, and W. M. Sischo. 1991 Preliminary field evidence for the association of clinical mastitis with altered interestrus intervals in dairy cattle. Theriogenology $36: 257-265$.

Moore, D. A., M. W. Overton, R. C. Chebel, M. L. Truscott, and H. BonDurant. 2005. Evaluation of factors that affect embryonic loss in dairy cattle. J. Am. Vet. Med. Assoc. 226:1112-1118.

National Mastitis Council. 1999. Laboratory Handbook on Bovine Mastitis. National Mastitis Council, Madison, WI.

Natzke, R. P., R. W. Everett, and D. R. Bray. 1975. Effect of drying off practices on mastitis infection. J. Dairy Sci. 58:1828-1835.

Newman, K. A., P. J. Rajala-Schultz, F. J. DeGraves, and J. Lakritz. 2010. Association of milk yield and infection status at dry-off with intramammary infections at subsequent calving. J. Dairy Res. 77:99-106.

Oliver, S. P. 1988. Frequency of isolation of environmental mastitiscausing pathogens and incidence of new intramammary infection during the nonlactating period. Am. J. Vet. Res. 49:1789-1793.

Oliver, S. P., R. A. Almeida, B. E. Gillespie, S. J. Headrick, H. H. Dowlen, D. L. Johnson, K. C. Lamar, S. T. Chester, and W. M. Moseley. 2004a. Extended ceftiofur therapy for treatment of experimentally-induced Streptococcus uberis mastitis in lactating dairy cattle. J. Dairy Sci. 87:3322-3329.

Oliver, S. P., B. E. Gillespie, S. J. Headrick, H. Moorehead, P. Lunn, H. H. Dowlen, D. L. Johnson, K. C. Lamar, S. T. Chester, and W. M. Moseley. 2004b. Efficacy of extended ceftiofur intramammary therapy for treatment of subclinical mastitis in lactating dairy cows. J. Dairy Sci. 87:2393-2400.

Pantoja, J. C. F., C. Hulland, and P. L. Ruegg. 2009a. Dynamics of somatic cell counts and intramammary infections across the dry period. Prev. Vet. Med. 90:43-54.

Pantoja, J. C. F., C. Hulland, and P. L. Ruegg. 2009b. Somatic cell count status across the dry period as a risk factor for the development of clinical mastitis in the subsequent lactation. J. Dairy Sci. 92:139-148.

Pinedo, P., C. Risco, and P. Melendez. 2011. A retrospective study on the association between different dry period lengths and somatic cell counts, milk yield, reproductive performance, and culling in Chilean dairy cows. J. Dairy Sci. 94:106-115.
Pinedo, P. J., P. Melendez, J. A. Villagomez-Cortes, and C. A. Risco. 2009. Effect of high somatic cell counts on reproductive performance of Chilean dairy cattle. J. Dairy Sci. 92:1575-1580.

Rastani, R. R., R. R. Grummer, S. J. Bertics, A. Gümen, M. C. Wiltbank, D. G. Mashek, and M. C. Schwab. 2005. Reducing dry period length to simplify feeding transition cows: Milk production, energy balance, and metabolic profiles. J. Dairy Sci. 88:1004-1014.

Reyher, K. K., and I. R. Dohoo. 2011. Diagnosing intramammary infections: Evaluation of composite milk samples to detect intramammary infections. J. Dairy Sci. 94:3387-3396.

Risco, C. A., G. A. Donovan, and J. Hernandez. 1999. Clinical mastitis associated with abortion in dairy cows. J. Dairy Sci. 82:16841689.

Santos, J. E. P., R. L. A. Cerri, M. A. Ballou, G. E. Higginbotham, and J. H. Kirk. 2004. Effect of timing of first clinical mastitis occurrence on lactational and reproductive performance of Holstein dairy cows. Anim. Reprod. Sci. 80:31-45.

Schukken, Y. H., G. J. Bennett, M. J. Zurakowski, H. L. Sharkey, B. J. Rauch, M. J. Thomas, B. Ceglowski, R. L. Saltman, N. Belomestnykh, and R. N. Zadoks. 2011. Randomized clinical trial to evaluate the efficacy of a 5-day ceftiofur hydrochloride intramammary treatment on nonsevere gram-negative clinical mastitis. J. Dairy Sci. 94:6203-6215

Schukken, Y. H., H. N. Erb, and R. D. Smith. 1988. The relationship between mastitis and retained placenta in a commercial population of Holstein dairy cows. Prev. Vet. Med. 5:181-190.

Schukken, Y. H., J. A. H. Smith, F. J. Grommers, D. Vandegeer, and A. Brand. 1989. Effect of freezing on bacteriologic culturing of mastitis milk samples. J. Dairy Sci. 72:1900-1906.

Sol, J., O. C. Sampimon, E. Hartman, and H. W. Barkema. 2002. Effect of preculture freezing and incubation on bacteriological isolation from subclinical mastitis samples. Vet. Microbiol. 85:241249.

Suriyasathaporn, W., Y. H. Schukken, M. Nielen, and A. Brand. 2000. Low somatic cell count: A risk factor for subsequent clinical mastitis in a dairy herd. J. Dairy Sci. 83:1248-1255.

van den Borne, B. H. P., J. C. M. Vernooij, A. M. Lupindu, G. van Schaik, K. Frankena, T. J. G. M. Lam, and M. Nielen. 2011. Relationship between somatic cell count status and subsequent clinical mastitis in Dutch dairy cows. Prev. Vet. Med. 102:265-273.

Watters, R. D., J. N. Guenther, A. E. Brickner, R. R. Rastani, P. M. Crump, P. W. Clark, and R. R. Grummer. 2008. Effects of dry period length on milk production and health of dairy cattle. J. Dairy Sci. 91:2595-2603.

Wenz, J. R., F. B. Garry, J. E. Lombard, R. Elia, D. Prentice, an R. P. Dinsmore. 2005. Short communication: Efficacy of parenteral ceftiofur for treatment of systemically mild clinical mastitis in dairy cattle. J. Dairy Sci. 88:3496-3499.

Whist, A. C., and O. Osterås. 2007. Associations between somatic cell counts at calving or prior to drying-off and clinical mastitis in the remaining or subsequent lactation. J. Dairy Res. 74:66-73.

Whist, A. C., O. Østerås, and L. Sølverød. 2006. Clinical mastitis in Norwegian herds after a combined selective dry-cow therapy and teat-dipping trial. J. Dairy Sci. 89:4649-4659.

Zadoks, R. N., H. G. Allore, H. W. Barkema, O. C. Sampimon, G. J. Wellenberg, Y. T. Gröhn, and Y. H. Schukken. 2001. Cow- and quarter-level risk factors for Streptococcus uberis and Staphylococcus aureus mastitis. J. Dairy Sci. 84:2649-2663. 